Jurnal The Messenger, Vol. 10, No. 1, January 2018, pp. 72-82

P-ISSN: 2086-1559, E-ISSN: 2527-2810

DOI: $10.26623 /$ themessenger.v10i1.716

\title{
Information Access Skills in Mothers as Containment of Internet Negative Impact
}

\section{Keterampilan Akses Informasi pada Ibu-Ibu sebagai Penanggulangan dari Dampak Negatif Internet}

\author{
Putri Limilia ${ }^{1}$, Benazir Bona $\mathbf{P}^{1}$ \\ ${ }^{1}$ Faculty of Communication Sciences, Universitas Padjadjaran, Jl. Raya Bandung \\ Sumedang KM 21, Jatinangor 45363, Indonesia \\ *Corresponding author, e-mail: p.limilia@unpad.ac.id
}

\begin{abstract}
Media and Information Literacy (MIL) skills was one of the skills that must be possessed by netizens. These skills become important in the effort of coping with the negative impact of the internet. The high penetration of the internet is not followed by the high skill of MIL. Therefore, the writers are interested to know the skills of information and media literacy (access skills) in mothers. This study uses descriptive quantitative method by using questionnaires as means of data collection. The result of the study shows that mothers tend to have moderate-level information access skills. The skills are reflected in the skills of mothers at moderate level in understanding the role of information, seeking sources of information, accessing information effectively and efficiently, and storing information.
\end{abstract}

Keywords: Media and Information Literacy, Information Access, Social Media, Mothers.

\begin{abstract}
Abstrak
Keterampilan literasi informasi dan media merupakan salah satu keterampilan yang harus dimiliki oleh warganet. Keterampilan ini menjadi penting dalam upaya menanggulangi dampak negatif dari internet. Tingginya penetrasi internet tidak diikuti dengan tingginya keterampilan tersebut. Oleh karena itu, penulis merasa tertarik untuk mengetahui keterampilan literasi informasi dan media (keterampilan akses) pada ibu-ibu. Penelitian ini menggunakan metode kuantitatif deskriptif dengan menggunakan kuisioner sebagai alat pengumpulan data. Hasil penelitan menunjukkan bahwa ibu-ibu cenderung memiliki keterampilan akses informasi dengan tingkatan sedang. Keterampilan tersebut tergambar dari keterampilan ibu-ibu ditingkat sedang dalam cara memahami peran informasi, mencari sumber informasi, mengakses informasi-informasi secara efektif dan efisien, dan juga menyimpan informasi tersebut.
\end{abstract}

Kata Kunci: Literasi Informasi dan Media, Akses Informasi, Media Sosial, Ibu-ibu.

Copyright () 2018 Universitas Semarang. All rights reserved.

\section{Introduction}

Internet users come from different age ranges. Children, adolescents, and adults can no longer be separated from the internet. Although, each generation has different abilities in the use. The largest internet penetration in Indonesia comes from the users ranging in age from 10-24 years (75.5\%) and 25-34 years (75.8\%) (APJII, 2016). Furthermore, APJII revealed that the profession of housewife $(16.6 \%)$ is the most internet users of the occupation category.

Internet penetration is not only massive among housewives but mothers with various professions. The research conducted by Sigma Research shows that $86.4 \%$ of mothers in Jakarta access the internet every day (source: indotelco.com). Similar 
research result is also stated by Marketers and MarkPlus. The research institute found that 5.4 million mothers spent three hours per day accessing the internet (source: solopos.com).

Internet usage among mothers is so active, does not only happen in Indonesia. Data reported by statista.com show that mothers, in America, spend 211 minutes every day in accessing the internet. Statista.com findings are also in line with the survey conducted by emarketers in America in 2017. The survey found that $95 \%$ of mothers in America were internet users with duration of usage three to three and half hours per day (source: emarketer.com).

The active internet usage is also accompanied by variety of online activities conducted by mothers. The various activities consist of seeking information (parenting, recipes, health), entertainment, communicating, and others. Some studies mention that the most frequently performed online activity by the mother is accessing social media. One of them is research conducted by Sigma Research. The research institute found that opening the chatting apps and social media are the most frequently performed activities by mothers with the most frequently accessed social media type is facebook.

The study entitled "Asian Digital Mum Survey 2015" conducted by The Asian Parents mentions that $91 \%$ of mothers in Indonesia have facebook account. This amount is more when compared to social media twitter (49\%) and instagram (48\%). The large number of facebook accounts are in line with the activities of mothers who diligently check the social media every day. The usage of facebook do not only to interact and communicate. However, the mothers also make facebook as means to get input or advice related to certain topics.

The high social media access is also found in mothers in the United States. The research conducted by emarketers (2017) found that nearly $90 \%$ of mothers were social media users (source: emarketer.com). Furthermore, the study found that 9 of 10 moms used facebook. This number is more when compared to other social media.

Currently, social media is not only used as medium for communicating and interacting with family or colleagues nearby. The function of social media turns into one source of information that has high credibility. That is because the information is disseminated by friends or colleagues who are known well. So, infrequently, the mother makes social media, especially facebook as their first reference source in finding solutions to the problems faced.

However, in the era of flood information, netizens are surrounded and even encircled by information that is sometimes not accountable for its validity. Such information is commonly referred to as "hoax/lie/misinformation". Hoax information is a type of information that the truth can not yet be accounted for. This is due to many factors such as the expertise of interviewee, motives of the people who disseminate information, and so on.

Hoax or lie information is usually disseminated through social media by broadcast system. This information is marked by bombastic title, an invitation to share or likes, or threats and losses when not redistribute the information. Moms are the target of hoax information dissemination. It is because mothers are lack of skills and carefulness in judging the truth of an information. They tend to be responsive and emotional so that faster in resharing the information.

The large number of mothers who become the target of internet abuse makes the writers interested to examine the extent of their ability or skills in identifying the needs

Jurnal The Messenger, Vol. 10, No. 1, January 2018, pp. 72-82 
of information, finding the information needed, and storing the information. Such skills are one of the components in Media and Information Literacy Skills.

Literacy of information and media is an ability or skill possessed by individuals in accessing, evaluating, and reproducing information. The definition is in line with the concept of information and media literacy offered by DW Akademie, namely "a set of skills that enable a person to access media, analyze media content, create new media messages, reflect on existing media content, and take action with media" (Karg \& Braesel, 2017: 2).

Meanwhile, UNESCO defines information and media literacy as:

"... an ability to access, obtain, understand, evaluate and use, create and share information and media content in various formats, using different types of tools, by applying critical, ethical, effective principles when participating and engaging in personal, professional and society interest" (UNESCO, 2013: 1).

Based on the above two definitions, we can see that information and media literacy are set of skills in other words information and media literacy consist of several sub-skills that must be possessed by each individuals. This sub-skill or component is the things that will make the individual literate information and media completely.

UNESCO and DW Akademie share the media and information literacy skills into different components or sub-skills. DW Akademie divides it into five components. Meanwhile, UNESCO divide it into three components. DW Akademie describes these five components into a model as the following.

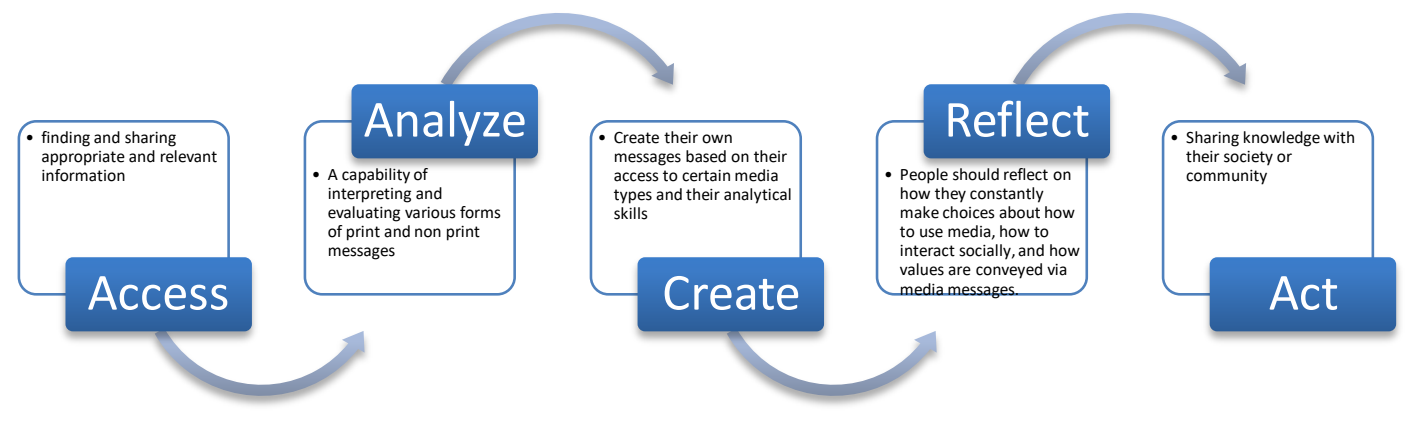

Diagram 1. Five Stages in the Development of Media and Information Literacy Skills (Karg \& Braesel, 2017)

Meanwhile, UNESCO as one of the active institutions in promoting media and information literacy skills offers different concept. UNESCO shares the information and media literacy into three components: access, evaluation, and production. The three competencies have sub-competencies as listed in the figure below.

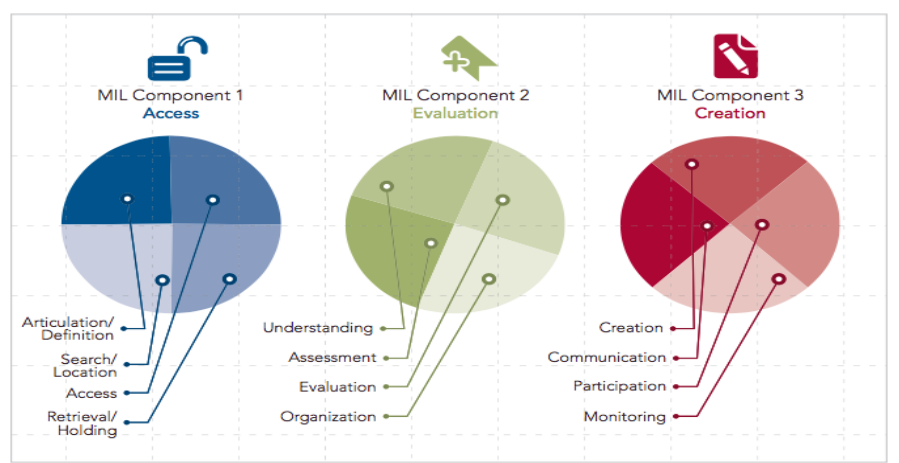

Figure 1. Competency of Media and Information Literacy 
The first competency of information and media literacy is access. UNESCO defines this competency as the ability to recognize and realiize the need for information and media contents. Meanwhile, the evaluation competency is the ability to understand and evaluate information and media accessed or consumed. The lattest competency is the ability to produce, use, and observe the information and media contents produced. These competencies are then translated into several sub-competencies and indicators.

\section{Methodology}

This study uses descriptive quantitative method because the purpose of study that wants to know the description of information and media literacy skills from the respondents. This study also uses crosstab analysis to determine the trends of age, occupation and education toward information and media litetation skills.

The respondents of this research are mothers of Keluarga Bina Remaja (Adolescent Youth Family) cadres in West Bandung regency. The sampling technique used is random with equal opportunity for every members of the population. Data collection technique was conducted by distributing questionnaires. The questionnaires consist of several statements and questions that are the adoption of UNESCO Global media and information literacy assessment framework: Country readiness and competencies.

\section{Result and Discussion}

The respondents of this study amounted to twenty-six people with sex are entirely female. The age of the respondents is relatively diverse with the largest percentage coming from the age category of 25-34 years (34.6\%) and 35-44 years (34.6\%). The rest, respondents' age are above 45 years. All respondents also have got married.

Most respondents work as housewives with percentage of $73.1 \%$ and work as nonhousewives $26.9 \%$. The respondents belong to the non-housewives category consist of various professions such as pre-school teacher, activist in the neighbourhood, PKK, BKR board, and others. Meanwhile, the last level of education most often taken by the respondents is senior high school with percentage of $46.2 \%$. The rest can be seen in the table below.

\begin{tabular}{|c|c|c|c|c|c|}
\hline & & Frequency & Percentage & $\begin{array}{c}\text { Valid } \\
\text { Percentage }\end{array}$ & $\begin{array}{l}\text { Cumulative } \\
\text { Percentage }\end{array}$ \\
\hline \multirow{5}{*}{ Valid } & Elementary School & 3 & 11.5 & 11.5 & 11.5 \\
\hline & Junior High School & 6 & 23.1 & 23.1 & 34.6 \\
\hline & Senior High School & 12 & 46.2 & 46.2 & 80.8 \\
\hline & $\mathrm{D} 3 / \mathrm{S} 1 / \mathrm{S} 2$ & 5 & 19.2 & 19.2 & 100.0 \\
\hline & Total & 26 & 100.0 & 100.0 & \\
\hline
\end{tabular}

Table 1. Educational Level of Respondents

The first component of UNESCO media and information literacy model is the skill to access. Access skill is the initial foundation for subsequent skills. UNESCO defines access skill as:

"... the ability to recognize the need for information, media content and knowledge and to be able to identify useful information and media content from all sources and formats, including print, audio, visual and digital to satisfy this need ..." (UNESCO, 2013: 1). 
Based on the above definition there are four sub-skills namely 1) the ability to recognize the role and scope of information from various sources; 2) the ability to know the right source of information; 3) the ability to access the source of information effectively and efficiently; 4) the ability to store information.

The ability of the respondents to recognize the role and scope of information from various sources that vary greatly. Table 2 shows that $42.3 \%$ of respondents have moderate ability in recognizing the role and scope of information from various sources that vary greatly. The rest, $26.9 \%$ of respondents have high and low ability in recognizing the role and scope of information from various sources that vary greatly.

\begin{tabular}{|c|c|c|c|c|}
\hline & Frequency & Percentage & $\begin{array}{c}\text { Valid } \\
\text { Percentage }\end{array}$ & $\begin{array}{l}\text { Cumulative } \\
\text { Percentage }\end{array}$ \\
\hline High & 7 & 26.9 & 28.0 & 28.0 \\
\hline Moderate & 11 & 42.3 & 44.0 & 72.0 \\
\hline Low & 7 & 26.9 & 28.0 & 100.0 \\
\hline Total & 25 & 96.2 & 100.0 & \\
\hline Missing System & 1 & 3.8 & & \\
\hline Total & 26 & 100.0 & & \\
\hline
\end{tabular}

Table 2. The Role and Scope of Information from Various Sources

The crosstab analysis conducted shows that respondents aged 25-34 years tend to have moderate $(44.4 \%)$ and low $(44.4 \%)$ ability in recognizing the role and scope of information from various sources. Meanwhile, 50\% of respondents aged 35-44 years have moderate ability and $37.5 \%$ of respondents over 45 years have moderate and high ability.

The respondents who work as working mothers tend to have percentage of high ability respondents (28.6\%) more than housewives $(27.8 \%)$, but each profession category, both housewives and working mothers, mostly have moderate ability in recognizing the role and scope of information from various sources.

The results of the analysis also found that respondents with elementary school and junior high school education have low ability in recognizing the role and scope of information from various sources, with the percentage of $66.7 \%$ (Elementary School) and 50\% (Junior High School). Meanwhile, the respondents with senior high school education and D3/S1/S2 were dominated by moderate-skilled respondents, with percentage of $66.7 \%$ for senior high school educated respondents and $50 \%$ for respondents with $\mathrm{D} 3 / \mathrm{S} 1 / \mathrm{S} 2$ education.

The next ability analyzed is the ability of respondents in finding and knowing the location of the right source of information. Table 3 shows that $46.2 \%$ of respondents have moderate ability in finding and knowing the location of the right source of information. The rest, $34.6 \%$ have low ability and $19.2 \%$ have high ability.

\begin{tabular}{|c|c|c|c|c|c|}
\hline & & Frequency & Percentage & $\begin{array}{c}\text { Valid } \\
\text { Percentage }\end{array}$ & $\begin{array}{l}\text { Cumulative } \\
\text { Percentage }\end{array}$ \\
\hline \multirow{4}{*}{ Valid } & High & 5 & 19.2 & 19.2 & 19.2 \\
\hline & Moderate & 12 & 46.2 & 46.2 & 65.4 \\
\hline & Low & 9 & 34.6 & 34.6 & 100.0 \\
\hline & Total & 26 & 100.0 & 100.0 & \\
\hline
\end{tabular}

Table 3. The Ability in Finding and Knowing the Location of Source of Information 
Crosstab analysis between age and ability to find and to know the location of the right information source suggests that respondents aged 25-34 years have higher number of high-ability respondents $(33.3 \%)$ than the 35-44 age group (11.1\%) and the over 45 years age group $(12.5 \%)$.

In addition, the analysis also found that groups aged 25-34 and 35-44 years tend to be dominated by moderate-skilled respondents with percentage of $44.4 \%$ and $66.7 \%$. Meanwhile, the age group above 45 years tends to be dominated by low-skilled respondents with percentage of $62.5 \%$.

\begin{tabular}{|c|c|c|c|c|c|c|}
\hline & \multicolumn{3}{|c|}{$\begin{array}{l}\text { Knowing Location of } \\
\text { Information } \\
\end{array}$} & \multirow[t]{2}{*}{ Total } \\
\hline & & & High & Moderate & Low & \\
\hline \multirow{4}{*}{ Education } & $\begin{array}{l}\text { Elementary } \\
\text { School }\end{array}$ & $\begin{array}{c}\text { Count } \\
\text { Expected Count } \\
\% \text { within } \\
\text { Education } \\
\end{array}$ & $\begin{array}{c}0 \\
.6 \\
0.0 \%\end{array}$ & $\begin{array}{c}1 \\
1.4 \\
33.3 \%\end{array}$ & $\begin{array}{c}2 \\
1.0 \\
66.7 \%\end{array}$ & $\begin{array}{c}3 \\
3.0 \\
100.0 \%\end{array}$ \\
\hline & $\begin{array}{l}\text { Junior } \\
\text { High } \\
\text { School }\end{array}$ & $\begin{array}{c}\text { Count } \\
\text { Expected Count } \\
\% \text { within } \\
\text { Education } \\
\end{array}$ & $\begin{array}{c}1 \\
1.2 \\
16.7 \%\end{array}$ & $\begin{array}{c}3 \\
2.8 \\
50.0 \%\end{array}$ & $\begin{array}{c}2 \\
2.1 \\
33.3 \%\end{array}$ & $\begin{array}{c}6 \\
6.0 \\
100.0 \%\end{array}$ \\
\hline & $\begin{array}{l}\text { Senior } \\
\text { High } \\
\text { School }\end{array}$ & $\begin{array}{c}\text { Count } \\
\text { Expected Count } \\
\% \text { within } \\
\text { Educationn } \\
\end{array}$ & $\begin{array}{c}2 \\
2.3 \\
16.7 \%\end{array}$ & $\begin{array}{c}6 \\
5.5 \\
50.0 \%\end{array}$ & $\begin{array}{c}4 \\
4.2 \\
33.3 \%\end{array}$ & $\begin{array}{c}12 \\
12.0 \\
100.0 \%\end{array}$ \\
\hline & $\mathrm{D} 3 / \mathrm{S} 1 / \mathrm{S} 2$ & $\begin{array}{c}\text { Count } \\
\text { Expected Count } \\
\% \text { within } \\
\text { Education }\end{array}$ & $\begin{array}{c}2 \\
1.0 \\
40.0 \%\end{array}$ & $\begin{array}{c}2 \\
2.3 \\
40.0 \%\end{array}$ & $\begin{array}{c}1 \\
1.7 \\
20.0 \%\end{array}$ & $\begin{array}{c}5 \\
5.0 \\
100.0 \%\end{array}$ \\
\hline \multicolumn{2}{|c|}{ Total } & $\begin{array}{c}\text { Count } \\
\text { Expected Count } \\
\% \text { within } \\
\text { Educationn }\end{array}$ & $\begin{array}{c}5 \\
5.0 \\
19.2 \%\end{array}$ & $\begin{array}{c}12 \\
12.0 \\
46.2 \%\end{array}$ & $\begin{array}{c}9 \\
9.0 \\
34.6 \%\end{array}$ & $\begin{array}{c}26 \\
26.0 \\
100.0 \%\end{array}$ \\
\hline
\end{tabular}

Table 4. Crosstab Analysis of Education with the Ability to Find and to Know the

Location of the Right Information Source

Table 4 shows that respondents with elementary and junior high school education levels tend to be dominated by low-ability respondents in finding and knowing the location of the right information sources. A total of $66.7 \%$ of respondents have elementary school education and $33.3 \%$ of respondents with junior high school education tend to have low ability. While the group of respondents with senior high school education and D3/S1/S2 are dominated by moderate ability in finding and knowing the location of the right information source. The number of respondents with senior high school education with moderate ability is $50 \%$. Whereas, the number of respondents with $\mathrm{D} 3 / \mathrm{S} 1 / \mathrm{S} 2$ with moderate ability is $40 \%$.

The respondents working as housewives tend to have moderate and low ability with percentage of $42.1 \%$ each. Meanwhile, the respondents working as working mothers tend to have moderate ability with percentage of $57.1 \%$ and $28.6 \%$ of respondents with high ability. 
The next component of the ability that becomes analysis material is the ability to access the information needed effectively and efficiently. The results show that $42.3 \%$ of respondents have low ability, $34.6 \%$ of respondents have moderate ability and the remaining $23.1 \%$ have high ability (table 5). Low ability tends to be owned by the respondents aged $35-44$ years $(55.6 \%)$ and age groups over 45 years $(37.5 \%)$. The $25-34$ years age group tends to be dominated by moderate-skilled respondents with percentage of $55.6 \%$. Meanwhile, high ability tends to be owned by the age group of 35-44 years with percentage of $33.3 \%$.

\begin{tabular}{|c|c|c|c|c|c|}
\hline & & Frequency & Percentage & Valid Percentage & Cumulative Percentage \\
\hline \multirow{4}{*}{ Valid } & High & 6 & 23.1 & 23.1 & 23.1 \\
\hline & Moderate & 9 & 34.6 & 34.6 & 57.7 \\
\hline & Low & 11 & 42.3 & 42.3 & 100.0 \\
\hline & Total & 26 & 100.0 & 100.0 & \\
\hline
\end{tabular}

Table 5. The Respondents' Ability in Accessing Information Needed Effectively and Efficiently

All respondents with elementary school education tend to have moderate ability in accessing information needed effectively and efficiently. This is very different from the respondents with junior high school education who mostly $(83.3 \%)$ tend to have low ability. Meanwhile, the ability of senior high school and D3/S1/S2 education tend to spread more in low, moderate and high level. The senior high school respondents tend to spread in three categories of ability with percentage of $33.3 \%$ each. D3/S1/S3 respondents tend to spread in two categories, high and low with percentage of $40 \%$ each.

The results of crosstab analysis in Table 6 show that housewives tend to have moderate and low ability in accessing information with percentage of $42.1 \%$ each. Meanwhile, working mothers tend to have high and low ability with percentage of $42.9 \%$ each.

\begin{tabular}{|c|c|c|c|c|c|c|}
\hline & & & \multicolumn{3}{|c|}{ Effective Information Access } & \multirow{2}{*}{ Total } \\
\hline & & & High & Moderate & Low & \\
\hline \multirow{6}{*}{$\begin{array}{l}\text { Occupa- } \\
\text { tion }\end{array}$} & \multirow{3}{*}{$\begin{array}{l}\text { House- } \\
\text { wife }\end{array}$} & Count & 3 & 8 & 8 & 19 \\
\hline & & Expected Count & 4.4 & 6.6 & 8.0 & 19.0 \\
\hline & & $\begin{array}{l}\% \text { within } \\
\text { occupation }\end{array}$ & $15.8 \%$ & $42.1 \%$ & $42.1 \%$ & $100.0 \%$ \\
\hline & \multirow{3}{*}{$\begin{array}{l}\text { Non- } \\
\text { house- } \\
\text { wife }\end{array}$} & Count & 3 & 1 & 3 & 7 \\
\hline & & Expected Count & 1.6 & 2.4 & 3.0 & 7.0 \\
\hline & & $\begin{array}{c}\% \text { within } \\
\text { Occupation }\end{array}$ & $42.9 \%$ & $14.3 \%$ & $42.9 \%$ & $100.0 \%$ \\
\hline \multirow{3}{*}{\multicolumn{2}{|c|}{ Total }} & Count & 6 & 9 & 11 & 26 \\
\hline & & Expected Count & 6.0 & 9.0 & 11.0 & 26.0 \\
\hline & & $\begin{array}{l}\% \text { within } \\
\text { Occupation }\end{array}$ & $23.1 \%$ & $34.6 \%$ & $42.3 \%$ & $100.0 \%$ \\
\hline
\end{tabular}

Table 6. Crosstab Analysis of Occupation and Ability to Access Information Effectively and Efficiently

The next ability that is also not less important is the individual ability or skills in storing information that have been obtained from some processes previously. This skill is important for the next stage in the media and information literacy model. The ability 
to store information can be either direct downloading activity or copying it to other media.

Table 7 shows that most respondents tend to have the ability to store information in the high and moderate categories with the percentage of $42.3 \%$, and only $15.4 \%$ of respondents are in low ability category. By age group, the respondents aged 25-34 years tend to be in the moderate category with percentage of 55.6\%. The respondents aged $35-$ 44 years tend to have high ability in storing information with percentage of $66.7 \%$, and the respondents aged over 45 years tend to have medium ability with percentage of $62.5 \%$. Although the respondents aged 35-44 years dominate high ability category, however this age group also dominates the low ability category with percentage of $22.2 \%$.

\begin{tabular}{|cc|c|c|c|c|}
\hline & Frequency & Percent & Valid Percent & $\begin{array}{c}\text { Cumulative } \\
\text { Percent }\end{array}$ \\
\hline \multirow{4}{*}{ Valid } & High & 11 & 42.3 & 42.3 & 42.3 \\
& Moderate & 11 & 42.3 & 42.3 & 84.6 \\
& Low & 4 & 15.4 & 15.4 & 100.0 \\
& Total & 26 & 100.0 & 100.0 & \\
\hline
\end{tabular}

Table 7. The Ability of The Respondents to Store Information

The respondents with elementary school education tend to spread in three categories of ability namely high, moderate, and low with percentage of $33.3 \%$ each. Meanwhile, $50 \%$ of the respondents with junior high school education tend to have moderate ability in storing information. Similarly, it is also found in respondents with senior high school education. Most of the respondents with senior high school education $(58.3 \%)$ tend to be categorized into moderate-skilled group. Whereas, D3/S1/S2 educated groups tend to have high ability in storing information with percentage of $80 \%$.

The respondents work as housewives tend to have moderate and high ability in storing information, with percentage of $47.4 \%$ of respondents belong to moderate category (table 8). Meanwhile, the respondents who work as working mothers tend to have high ability in storing information with percentage of $71.4 \%$ and $28.6 \%$ in the moderate category.

\begin{tabular}{|c|c|c|c|c|c|c|}
\hline & & & \multicolumn{3}{|c|}{ Storing Information } & \multirow{2}{*}{ Total } \\
\hline & & & High & Moderate & Low & \\
\hline \multirow{2}{*}{$\begin{array}{l}\text { Occupa- } \\
\text { tion }\end{array}$} & $\begin{array}{c}\text { House- } \\
\text { wife }\end{array}$ & $\begin{array}{c}\text { Count } \\
\text { Expected Count } \\
\% \text { within Occupation }\end{array}$ & $\begin{array}{c}6 \\
8.0 \\
31.6 \%\end{array}$ & $\begin{array}{c}9 \\
8.0 \\
47.4 \%\end{array}$ & $\begin{array}{c}4 \\
2.9 \\
21.1 \%\end{array}$ & $\begin{array}{c}19 \\
19.0 \\
100.0 \%\end{array}$ \\
\hline & $\begin{array}{l}\text { Non- } \\
\text { House- } \\
\text { wife }\end{array}$ & $\begin{array}{c}\text { Count } \\
\text { Expected Count } \\
\% \text { within Occupation }\end{array}$ & $\begin{array}{c}5 \\
3.0 \\
71.4 \% \\
\end{array}$ & $\begin{array}{c}2 \\
3.0 \\
28.6 \%\end{array}$ & $\begin{array}{c}0 \\
1.1 \\
0.0 \%\end{array}$ & $\begin{array}{c}7 \\
7.0 \\
100.0 \%\end{array}$ \\
\hline \multicolumn{2}{|c|}{ Total } & $\begin{array}{c}\text { Count } \\
\text { Expected Count } \\
\% \text { within Occupation }\end{array}$ & $\begin{array}{c}11 \\
11.0 \\
42.3 \%\end{array}$ & $\begin{array}{c}11 \\
11.0 \\
42.3 \%\end{array}$ & $\begin{array}{c}4 \\
4.0 \\
15.4 \%\end{array}$ & $\begin{array}{c}26 \\
26.0 \\
100.0 \%\end{array}$ \\
\hline
\end{tabular}

Table 8. Crosstab Analysis of Occupation with The Ability of Storing Information After giving the description of some components of the above access skills, the writers analyzed the overall access components further. The results of the analysis in Table 9 show that the skills of the respondents tend to spread across three categories of 
skill levels with not too much percentage difference. $42.3 \%$ of respondents are categorized as individuals with moderate skills in accessing information. Meanwhile, $30.8 \%$ of respondents are still classified into low skilled category and only $23.1 \%$ of respondents have high skill level.

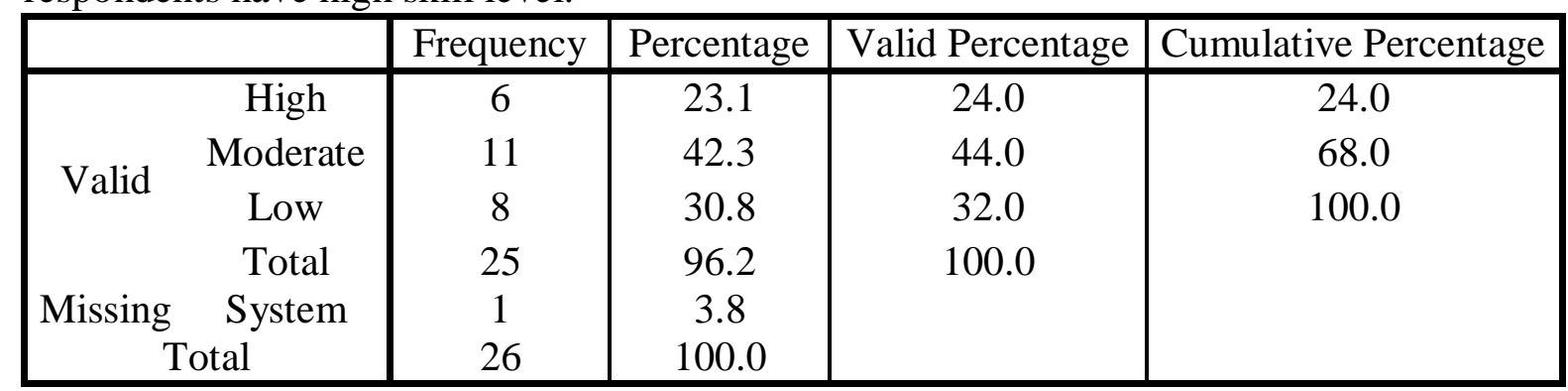

Table 9. Access Skill of Respondents

The respondents with high access skill level are from the 35-44 age group with percentage of $12 \%$. The 35-44 years and 45 years above age groups tend to have moderate skill level of $16 \%$ each. Meanwhile, the 25-34 years age group tends to have low skill levels with percentage of $16 \%$.

The low access skill is also likely to be found in elementary school educated respondents of $8 \%$ and junior high school education of $16 \%$. Seniot high schooleducated respondents tend to have moderate skill level with percentage of $28 \%$ and high skill level of $12 \%$. Whereas, D3/S1/S2 educated respondents tend to be in moderate and high category with percentage of $8 \%$ each.

Housewives tend to have moderate and high skills. As many as $32 \%$ of housewives belong to the moderate category and $28 \%$ are included into the low category with percentage of $28 \%$. Meanwhile, working mothers tend to have moderate and high skill levels with percentage of $12 \%$ for each category.

Thus, it can be concluded that the skills of women's information access are mostly at moderate level. Where this moderate level reflects the average level of mothers' access skills, which includes four components namely, 1) the ability to recognize the role and scope of information from various sources; 2) the ability to know the right source of information; 3) the ability to access information resources effectively and efficiently; 4) the ability to store information.

Basically, this information access skill is related to the daily information behavior of human as illustrated in Model of Seeking and Using of Information by Williamson. This model is the result of large-scale study focusing on parents and daily information. In terms of the search and use of daily information, this model emphasizes that in everyday life information is often obtained accidentaly rather than deliberately sought for particular purpose. Williamson argues that not all information are obtained by being sought, because not all human information behavior are deliberate behavior that has particular purpose. Therefore Williamson chooses to use the term "obtaining information accidentally" in Model of Information Seeking and Use (Fisher, et. al, 2008: 128).

This is what the respondent mothers tend to show in their daily information behavior. Instead of seeking certain information with particular purpose deliberately, most of the respondents mothers information needs are met accidentally, where they get information while they are doing other activities when using gadget or consuming other media, such as television, radio, etc. Every day the respondents mothers are flooded with variety of information so that indirectly this has fulfilled their daily information 
needs. Therefore, they do not have enough motivation to literate themselves with the ability to seek and consume information intentionally. The absence of motivation to self-literacy with the ability to access information is what causes the level of access skills of most of the respondents mothers tend to be moderate.

The result of this study indicates that the absence of literacy skills of information and media begins from the low knowledge of the mothers about the role of information and media that exist today. Low skills in recognizing the role of information and media tend to be found in mothers aged 25-34 years and elementary school and junior high school educated.

In general, mothers tend to have moderate skill level in seeking and finding the right source of information. The high skill level in seeking information is likely to be owned by mothers aged 25-34 years and D3/S1/S2 educated. Whereas, elementary school and junior high school educated tend to have low skill level.

The result also show that most mothers have low skill in accessing information effectively and efficiently. The low skill level is likely to be owned by mothers aged 3544 years and junior high school educated. The last skill component is the skill to store the information that has been accessed. Most mothers tend to have high and moderate skills. The high skill tends to be owned by mothers aged 35-44 years, D3/S1/S2 educated, and work as working mother.

The skill of media and information literacy is very needed in overcoming the negative impact of the internet. Several profit and non-profit institutions both at international and national level have begun to popularize this concept. However, in practice there are still many people, especially netizens who have not understood and owned this skill. One of them is the mothers who often become the victims of the internet.

The absence of literacy skills of information and media in mothers tends to make them easily exposed to lying information, unable to meet the main information needs, and so on.

\section{Conclusion}

In the media and information literacy model, UNESCO defines access skill consists of four sub-skills, namely: 1) the ability to recognize the role and scope of information from various sources; 2) the ability to know the right source of information; 3 ) the ability to access source of information effectively and efficiently; 4) the ability to store information.

Access skill is skill that is at level 1 . The result of this study found that most mothers tend to have moderate access skill level. High access skill tends to be owned by mothers aged 35-44 years, D3/S1/S2 educated, and work as working mother.

The findings above are certainly not separated from the various shortcomings. Therefore, the writers suggest that future research may use mix methods in order to dig deeper the factors that lead to high skill.

\section{Acknowledgement}

The writers would like to thank Universitas Padjadjaran who has financed this research and also we would like to thank Faculty of Communication Sciences who has supported this research and last but not least we would like to thank Dinas Pemberdayaan Perempuan Perlindungan Anak dan Keluarga Berencana of West Bandung District for the technical support during data collection in the field. 


\section{References}

APJII. (2016). Penetrasi \& Perilaku Pengguna Internet Indonesia. Jakarta.

Emarketers. (2017). US Mothers' Digital Usage: What Matters More, What Matters Less. $\quad$ https://www.emarketer.com/Report/US-Mothers-Digital-Usage-WhatMatters-More-What-Matters-Less/2002075.

Fisher, K.E., Erdelez, S., \& McKechnie, L. (2008). Theories of Information Behavior. New Jersey: Information Today, Inc.

Hafnie, A.N. (2014). Tren Penggunaan Smartphone di Kalangan Ibu Rumah Tangga. http://www.solopos.com/2014/09/30/tren-penggunaan-smartphone-di-kalanganibu-rumah-tangga-540698.

Karg, T., \& Braesel, S. (2017). Edition DW Akademie | Media and Information Literacy: A Practical Guidebook for Trainers (H. Walsh, Ed.). Germany: Deutsche Welle.

UNESCO. (2013). Global Media and Information Literacy Assessment Framework: Country Readiness and Competencies. Paris: UNESCO.

http://www.indotelko.com/kanal?c=pi\&it=profil-penggunaan-internet-ibu-muda 